\title{
ESTIMATION THE ANTIBACTERIAL EFFECT OF CURCUMIN AND ROSEMARY AMONG PATIENTS WITH DENTAL CARIES IN VITRO
}

\author{
EHAN ABDULHADI AL-SHARIFI ${ }^{1 *}$, ASIA ABED AL-MAHMOOD², SUMAYAH AL-MAHMOOD ${ }^{2}$
}

${ }^{1}$ Department of Basic Sciences, College of Dentistry, Ibn Sina University of Medical and Pharmaceutical Sciences, Baghdad, Iraq ${ }^{2}$ Department of Basic Sciences, College of Dentistry, Al-Iraqia University, Baghdad, Iraq. Email: dr.ehanabdulhadi@gmail.com

Received: 03 November 2018, Revised and Accepted: 24 December 2018

\section{ABSTRACT}

Objective: The aim is to estimate the effect of curcumin and rosemary as antibacterial agents among dental caries cases.

Methods: Samples of saliva were randomly collected from 40 patients in Al-Furat General Hospital who attended the hospital from July to September 2018. Swabs were cultured on blood agar at $37^{\circ} \mathrm{C}$ for $24 \mathrm{~h}$ and then subcultured in mannitol salt agar and trypticase soy broth at $37^{\circ} \mathrm{C}$ for $24 \mathrm{~h}$. Different concentrations of aqueous extract curcumin solution $(0.1,0.3,0.5$, and $1 \mathrm{mg} / \mathrm{ml})$ and rosemary solution ( $1 \mathrm{~g} / \mathrm{ml})$ were prepared and added to the bacterial culture. Later, minimum inhibition zones of the bacterial cultures were determined.

Results: The results showed that there were 25 cases of Streptococcus mutans, 10 cases of Staphylococcus aureus, 3 cases of anaerobic bacteria, and 2 cases of normal flora among 40 culturing swabs of bacteria. Aqueous extract of curcumin showed antibacterial effect with concentrations ( 0.1 , 0.3 , 0.5 , and $1 \mathrm{mg} / \mathrm{ml}$ ) against oral bacteria; nevertheless, these bacteria were resistant to the aqueous extract of rosemary with concentration $1 \mathrm{~g} / \mathrm{ml}$.

Conclusion: It can be concluded that curcumin can be an effective antibacterial agent against dental caries disease and its effect increases positively in relation to its concentration. On the other hand, rosemary with $1 \mathrm{~g} / \mathrm{ml}$ concentration did not show any effect on oral bacteria.

Keywords: Curcumin, Rosemary, Dental caries.

(C) 2019 The Authors. Published by Innovare Academic Sciences Pvt Ltd. This is an open access article under the CC BY license (http://creativecommons. org/licenses/by/4. 0/) DOI: http://dx.doi.org/10.22159/ajpcr.2019.v12i3.30378

\section{INTRODUCTION}

Teeth caries and cavities are the major forms of mouth health problem approximately $36 \%$ of the population worldwide have dental caries in their permanent teeth [1]. Streptococcus mutans is a pathogen bacterium associated with dental caries and cavities. $S$. mutans bacteria form a colony on teeth surface as dental plaque and convert extracellular polysaccharide to lactic acid through fermentation and eventually caused teeth caries [2,3]. Toothpaste and mouthwash which are used in mouth care can contain natural components as thymol or synthetic components like chlorhexidine; however, those containing synthetic ingredients are usually associated with teeth staining $[4,5]$

Turmeric (the common name of curcumin) is cultivated in India and other parts of Southeast Asia. It has a long history used as an antiinflammatory in Ayurvedic medicine [6]. Curcumin is lipophilic, but it is quite stable in acidic pH of the stomach. Due to its low rate of absorption, curcumin is often formulated with bromelain for higher absorption [7-11]. Curcumin is showed anti-inflammatory, antioxidants, antimutagenic, and antimicrobial activity [6,12,13,14,15-18]. In addition, curcumin can be applied in the dental field as in dental pain by massaging the aching teeth, mouthwash, periodontal problem by topical application, subgingival irritant, scaling, and root planning [19-22].

Rosemary (Rosmarinus officinalis) is a common aromatic evergreen shrub grown in many parts of the world. It showed antioxidant and anti-inflammatory effects against different types of bacteria. The fresh and dried leaves are mostly used as a food preservative and flavoring agent in traditional Mediterranean cuisine [23-25].

Herbal therapies such as curcumin and rosemary that showed powerful antioxidant and anti-inflammatory activity can be used for the prevention and treatment of dental caries disease as well as to overcome the problem of teeth staining accompanied using a mouthwash containing synthetic substances due to their natural components.

\section{METHODS}

\section{Sample collection}

This study was conducted with 40 patients attended the Al-Furat General Hospital/Dentistry Department in Baghdad, Iraq, from July to September 2018. Protocol approval was achieved from the AlFurat General Hospital; furthermore, the Ethical Committee Approval was achieved for the protocol before starting the study. Swabs were cultured on blood agar plates at $37^{\circ} \mathrm{C}$ for $24 \mathrm{~h}$ and then subcultured in mannitol salt agar and trypticase soy broth at $37^{\circ} \mathrm{C}$ for $24 \mathrm{~h}$. Later, bacteria types were confirmed by typical morphologies under a dissecting microscope.

\section{Plant extraction}

Preparation of aqueous extract of curcumin

Curcumin leaves were bought from the local market. $100 \mathrm{~g}$ of curcumin crushed and converted to powder and added to $1000 \mathrm{ml}$ of boiling water in a sterilized conical flask over low flame for $15 \mathrm{~min}$. The flask was then plugged and removed from the heat and allowed to cool. Later, the contents of the flask were filtered to prepare the required concentrations of $0.1,0.3,0.5$, and $1 \mathrm{mg} / \mathrm{ml}[26]$.

\section{Preparation of aqueous extract of rosemary}

Rosemary leaves were bought from the local market, crushed and converted to powder. $50 \mathrm{~g}$ of leaves powder were extracted for $3 \mathrm{~h}$ in $500 \mathrm{ml}$ of the sterilized distilled water using the Soxhlet device, and the source of heating was a boiling water bath $100^{\circ} \mathrm{C}$. The leaf extract solution was then evaporated at $45^{\circ} \mathrm{C}$ using a rotary evaporator, and the resultant crude extract was frozen at $-20^{\circ} \mathrm{C}$ until use to prepare the required concentration of $1 \mathrm{~g} / \mathrm{ml}[27,28]$. 
Minimum inhibitory concentration determination

Minimum inhibition concentration was determined for bacterial cultures after the addition of different concentration of curcumin and rosemary aqueous extract solution.

\section{Data analysis}

Data were expressed as mean \pm standard deviation with $\mathrm{p}<0.01$ to be considered as highly significant where $\mathrm{p}<0.05$ to be considered as significant. Chi-square and unpaired $t$-test were used to compare the concentrations of curcumin and minimum inhibition zone.

\section{RESULTS}

A total of 40 swabs were cultivated on blood agar at $37^{\circ} \mathrm{C}$ for $24 \mathrm{~h}$ and then were subcultured in mannitol salt agar and trypticase soy broth at $37^{\circ} \mathrm{C}$ for 24 h. Fig. 1 reveals that the most frequently isolated bacteria by culture was $S$. mutans (62\%), followed by Staphylococcus aureus $(25 \%)$, anaerobic bacteria (8\%), and normal flora (5\%). Fig. 2 reveals the number of different types of bacteria that were identified from the 40 swabs.

According to the effects of curcumin concentrations on bacterial growth, it has been found that the inhibition zone diameter of bacterial growth increases with increase in the curcumin concentration (Fig. 3). On the other hand, the rosemary did not show any effect on the bacterial growth with the concentration $1 \mathrm{~g} / \mathrm{ml}$.

\section{DISCUSSION}

Dental caries is the most common oral disease worldwide. It can be caused by different multifactorial, most of them are the presence of endogenous bacteria such as $S$. mutans [29]. Natural herbs such as curcumin and rosemary showed antibacterial and antioxidants and can be used in the prevention and treatment of disease. They can be used instead of chemotherapeutics due to their natural constituents. In addition, they can be used alternatively of antibiotics treatment to overcome the problem of high bacterial resistant [30]. In our study, mutans Streptococci was the most bacteria species found among dental caries cases, and this is in agreement with Bowen et al. as this bacterium is a power producing of acid rapidly and a proximal causing of dental caries [31]. Moreover, other factors should be considered into account as pH. Although many organisms have the ability to form acid immediately, many plaque biofilms have the capacity to form alkali. Thus, it is common to observe that the $\mathrm{pH}$ value of plaque without exposed to sugars overnight may be more alkaline than the surrounding saliva. Furthermore, the presence of other bacteria such as lactobacilli and actinomycetes have a major role in the etiology of dental caries disease [32].

In our study, the strongest effect of curcumin as an antibacterial agent (in vitro) was detected at a concentration of $1 \mathrm{mg}$ and a linear correlation was found between the curcumin concentration and the inhibitory zone of bacteria. This is in agreement with the study of Aday et al. and Song et al., which supports the ability of curcumin to show antiadhesive activity as well as inhibit the growth of Gram-positive and Gram-negative bacteria [33,34]. However, curcumin cannot be used widely in the treatment of diseases due to its water insolubility and poor bioavailability in the body system according to Bharali et al. and Al-Musawi et al.; therefore, using alcoholic extract more than the aqueous extract of curcumin can improve the antibacterial activity of curcumin.[35,36].

Furthermore, the rosemary did not show any effect on bacterial growth, and this is in agreement with Jawad et al. that extract of rosemary showed a wide range of antibacterial activity against positive and negative bacteria like Escherichia coli [37]. The extract of rosemary contains phenols which have the ability of inhibition on the cell walls and cell membranes synthesis, nucleic acid metabolism and on the Gram-positive and Gram-negative bacteria and wide

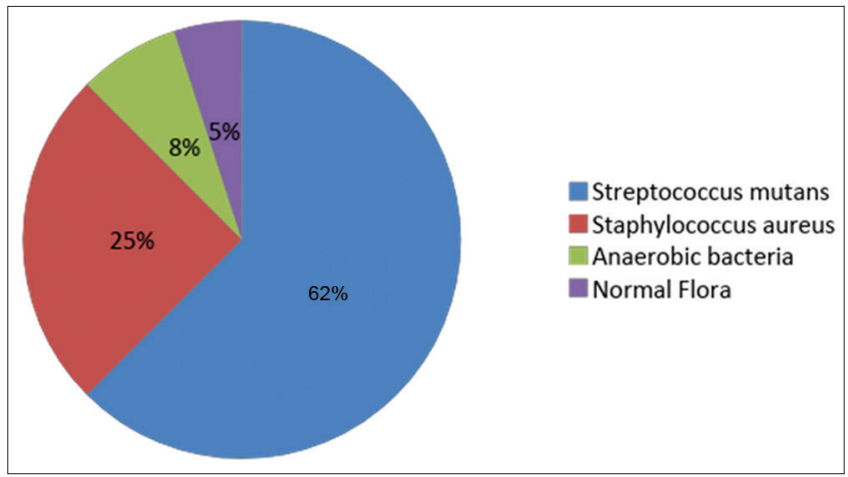

Fig. 1: Distribution of the frequency of bacteria types according to the swab culture

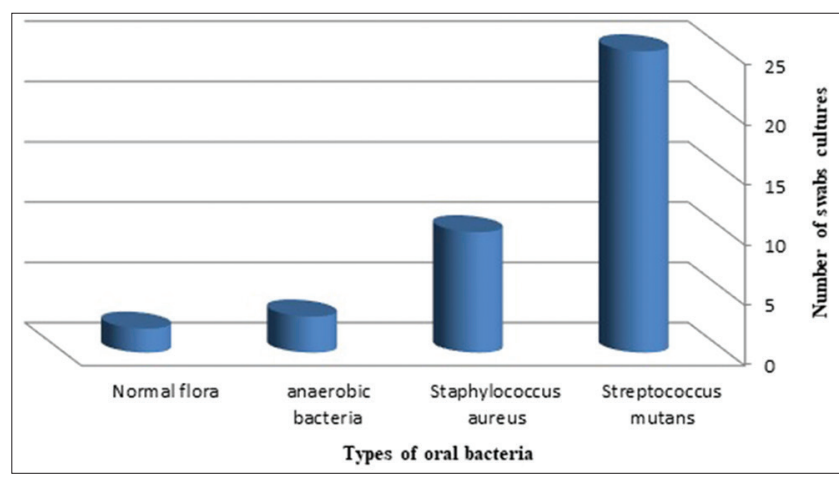

Fig. 2: Distribution of bacterial types according to oral swabs cultures. Data presented as Chi-square. Sample size (n) $=40$.

Chi-square statistic is 15.5311. $p<0.01$ to be considered as highly significant where $p<0.05$ to be considered as significant

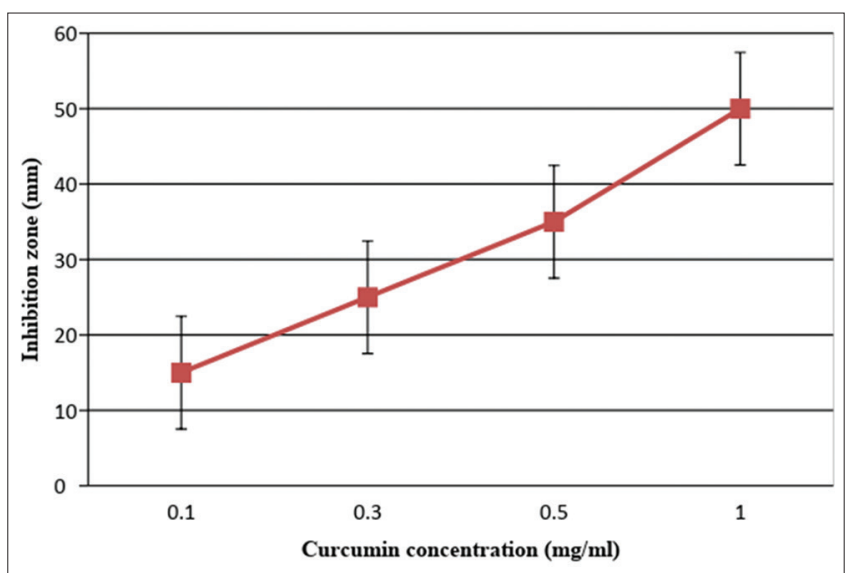

Fig. 3: The relationship between the inhibition zone diameter of oral bacteria and the curcumin's concentrations. Data presented as curcumin concentration $(\mathrm{mg} / \mathrm{ml})$ mean $\pm \mathrm{SD}(0.475 \pm 0.386)$ and inhibition zone $(\mathrm{mm})$ mean \pm SD $(31.25 \pm 14.93)$. Unpaired t-test was used to compare concentration of curcumin and inhibition zone diameters; $\mathrm{p}<0.01$ to be considered as highly significant where $\mathrm{p}<0.05$ to be considered as significant

range on bacteria and fungi inhibition. Accordingly, using alcoholic or oil extract of rosemary can give stronger antibacterial activity than the aqueous extract of rosemary [38,39]. In addition, other factors such as $\mathrm{pH}$ and temperature of the extract solution should be considered in determining its antibacterial activity according to Ali et al. [40]. 


\section{CONCLUSION}

Curcumin showed antibacterial activity against oral bacteria and its activity increase proportionally with its concentration; however, the rosemary with concentration $1 \mathrm{~g} / \mathrm{ml}$ did not show any activity against these bacteria.

\section{ACKNOWLEDGMENT}

We are thankful to Al-Furat General Hospital/Dentistry Department in Baghdad, Iraq, for helping to carry this research to a conducive outcome.

\section{AUTHOR'S CONTRIBUTIONS}

All the authors played a key role in carrying out the study to a conducive outcome. Data collection and implementation of the research were done by the first author. Study design and data analysis were done by the second and third authors. All the authors were involved in the critical revision the final approval of the version to be published.

\section{CONFLICTS OF INTEREST}

The authors declare that there are no conflicts of interest.

\section{REFERENCES}

1. Murray CJ, Vos T, Lozano R, Naghavi M, Flaxman AD, Michaud C, et al. Disability-adjusted life years (DALYs) for 291 diseases and injuries in 21 regions, 1990-2010: A systematic analysis for the global burden of disease study 2010. Lancet 2012;380:2197-223.

2. Loesche WJ. Microbiology of dental decay and periodontal disease. In: Baron S, editor. Medical Microbiology. $4^{\text {th }}$ ed. Galveston (TX): University of Texas Medical Branch at Galveston; 1996.

3. Busri A, Puspitawati R, Utami S. Antibacterial effect of java turmeric ethanol extract against dual-species Streptococcus mutans and Streptococcus sanguinis Biofilm (in vitro). Asian J Pharm Clin Res 2017;10:23087.

4. Rukayadi Y, Hwang JK. In vitro activity of xanthorrhizol against Streptococcus mutans biofilms. Lett Appl Microbiol 2006;42:400-4.

5. Eley BM. Antibacterial agents in the control of supragingival plaque - a review. Br Dent J 1999;186:286-96.

6. Ammon HP, Wahl MA. Pharmacology of curcuma longa. Planta Med 1991;57:1-7.

7. National Toxicology Program. NTP toxicology and carcinogenesis studies of turmeric oleoresin (CAS no 8024-37-1) (Major component $79 \%-85 \%$ curcumin, CAS no $458-37-7)$ in $\mathrm{F} 344 / \mathrm{N}$ rats and B6C3F1 mice (Feed studies). Natl Toxicol Program Tech Rep Ser 1993;427:1-275

8. Wang YJ, Pan MH, Cheng AL, Lin LI, Ho YS, Hsieh CY, et al. Stability of curcumin in buffer solutions and characterization of its degradation products. J Pharm Biomed Anal 1997;15:1867-76.

9. Wahlström B, Blennow G. A study on the fate of curcumin in the rat. Acta Pharmacol Toxicol (Copenh) 1978;43:86-92.

10. Aggarwal BB, Kumar A, Bharti AC. Anticancer potential of curcumin: Preclinical and clinical studies. Anticancer Res 2003;23:363-98.

11. Abraham A, Samuel S, Mathew L. Pharmacognostic evaluation of Curcuma long $a \mathrm{~L}$. Rhizome and standardization of its formulation by HPLC using curcumin as marker. Int J Pharm Phytochem Res 2018;10:38-42.

12. Negi PS, Jayaprakasha GK, Jagan Mohan Rao L, Sakariah KK. Antibacterial activity of turmeric oil: A byproduct from curcumin manufacture. J Agric Food Chem 1999;47:4297-300.

13. Ramirez-Boscd A, Soler A, Gutierrez AC, Alvarez JL, Almagro EQ. Antioxidant Curcuma extracts decrease the blood lipid peroxide levels of human subjects. Age (Omaha) 1995; 18:167-9.

14. Toda S, Miyase T, Arichi H, Tanizawa H, Takino Y. Natural antioxidants. III. Antioxidative components isolated from rhizome of Curcuma longa L. Chem Pharm Bull (Tokyo) 1985;33:1725-8.

15. Mehta K, Pantazis P, McQueen T, Aggarwal BB. Antiproliferative effect of curcumin (diferuloylmethane) against human breast tumor cell lines. Anticancer Drugs 1997;8:470-81.

16. Sharma OP. Antioxidant activity of curcumin and related compounds. Biochem Pharmacol 1976;25:1811-2.

17. Chaturvedi TP. Uses of turmeric in dentistry: An update. Indian J Dent Res 2009;20:107-9.

18. Abbas SH, Abdulridha MK, Najeb AA. Potential benefit of curcumin adjuvant therapy to the standard Helicobacter pylori eradication therapy in patients with peptic ulcer disease. Asian J Pharm Clin Res 2017; 10:313-7.

19. Çıkrıkçı S, Mozioğlu E, Yılmaz H. Biological activity of curcuminoids isolated from Curcuma longa. Rec Nat Prod 2008;2:19-24.

20. Lal B, Kapoor AK, Asthana OP, Agrawal PK, Prasad R, Kumar P, et al. Efficacy of curcumin in the management of chronic anterior uveitis. Phytother Res 1999;13:318-22.

21. Behal R, Mali AM, Gilda SS, Paradkar AR. Evaluation of local drugdelivery system containing $2 \%$ whole turmeric gel used as an adjunct to scaling and root planing in chronic periodontitis: A clinical and microbiological study. J Indian Soc Periodontol 2011;15:35-8

22. Suhag A, Dixit J, Prakash D. Role of curcumin as a subgingival irrigant: A pilot study. Periodental Pract Today 2007;4:115-21.

23. Ulbricht C, Windsor RC, Brigham A, Bryan JK, Conquer J, Costa D, et al. An evidence-based systematic review of annatto (Bixa orellana $\mathrm{L}$.) by the natural standard research collaboration. J Diet Suppl 2012;9:57-77.

24. Klancnik A, Guzej B, Kolar MH, Abramovic H, Mozina SS. In vitro antimicrobial and antioxidant activity of commercial rosemary extract formulations. J Food Prot 2009;72:1744-52

25. Rosselló JA, Cosín R, Boscaiu M, Vicente O, Martínez I, Soriano P. Intragenomic diversity and phylogenetic systematics of wild rosemaries (Rosmarinus officinalis L. s.l., Lamiaceae) assessed by nuclear ribosomal DNA sequences (ITS). Plant Syst Evol 2006;262:1-12.

26. Maha FA, Hadeel WA. The effect of aqueous extract of Curcuma longa on some parameters of cytogenetic, immunity and fertility in female mice. J Coll Basic Educ 2013;19:889-97.

27. Ibrahim RM. Effect of aqueous extract of Rosemary officinalis on cytotoxicity of CCL4 induced albino male mice. J Biotechnol Res Cent 2018;12:10

28. Abozid M, Farid HE. Protective role and antioxidant activity of aqueous extract of Rosmarinus Officinalis against trichlorocetate--induced toxicity in liver of male rats. Asian J Pharm Clin Res 2018;11:420-4.

29. Selwitz RH, Ismail AI, Pitts NB. Dental caries. Lancet 2007;369:51-9.

30. Basheer AI. Effect of alcoholic extract of rosmarinus against some type of Entrobacteriaceae. Tikrit J Pure Sci 2018;23:18-21.

31. Bowen WH. Dental caries - Not just holes in teeth! A perspective. Mol Oral Microbiol 2016;31:228-33.

32. Tanzer JM, Livingston J, Thompson AM. The microbiology of primary dental caries in humans. J Dent Educ 2001;65:1028-37.

33. Aday HA. Bioactivity of curcumin extract against of some pathogenic strains. Eng Tech J 2011;29:2087-92.

34. Song J, Choi B, Jin EJ, Yoon Y, Choi KH. Curcumin suppresses Streptococcus mutans adherence to human tooth surfaces and extracellular matrix proteins. Eur J Clin Microbiol Infect Dis 2012;31:1347-52.

35. Bharali DJ, Siddiqui IA, Adhami VM, Chamcheu JC, Aldahmash AM, Mukhtar $\mathrm{H}$, et al. Nanoparticle delivery of natural products in the prevention and treatment of cancers: Current status and future prospects. Cancers (Basel) 2011;3:4024-45.

36. Al-musawi S. Folated-nanocarrier for curcumin drug delivery in breast cancer therapy. Eng Tech J 2015;3:1643-54.

37. Jawad AM, Allawi AK, Mufeed EH. Essential oils of rosemary as antimicrobial agent against three types of bacteria. Med J Babylon 2018;15:1-6

38. Campo JD, Amiot MA, Nguyen TC. Antimicrobial effect of rosemary extracts. J Food Prot 2000;63:1359-68.

39. Das S, Mandal SK. Current developments on anti-inflammatory natural medicines. Asian J Pharm Clin Res 2018;11:61-5.

40. Ali HI, Ali DS. Evaluation of the inhibitory effect of the water, alcohol and oil extract of Rosmarinus officinalis L. In some pathogenic bacteria. Al-Muthanna J Agric 2018;6:41-7. 